\title{
Detection of Biofilm Genes (IcaA and IcaD) in Staphylococcus spp.
}

\author{
Aws I. Sulaiman \\ Basima A. Abdulla \\ Department of Biology/College of Science / University of Mosul
}

Email: aws_isulaiman@yahoo.com, aws.isulaiman36@gmail.com

(Received 20/6/2018; Accepted 1 / 11/2018)

\begin{abstract}
One hundred thirty one clinical bacterial samples were collected from skin, pus, urine and blood from patients at Al-Salam General Teaching Hospital in Mosul city during March until July/ 2012, The present study included identification using API ID 32 STAPH system to the species Staphylococcus. aureus, Staph. lugdunensis, Staph. epidermidis, Staph. hominis, Staph. auricularis and Staph. haemolyticus, Biofilm formation genes at icaA (188 bp.) were found in $35.7 \%$ of Staph. aureus, Staph. hominis, and Staph. xylosus but $42.8 \%$ of Staph. aureus, Staph. epidermidis, Staph. hominis, and Staph. xylosus contained icaD (198 bp.) gene only.
\end{abstract}

Keywords: Staphylococcus, icaA, icaD.

Staphylococcus Spp. تحديد جينات (IcaA و المكونة للأغثية الحيوية لأفراد جنس

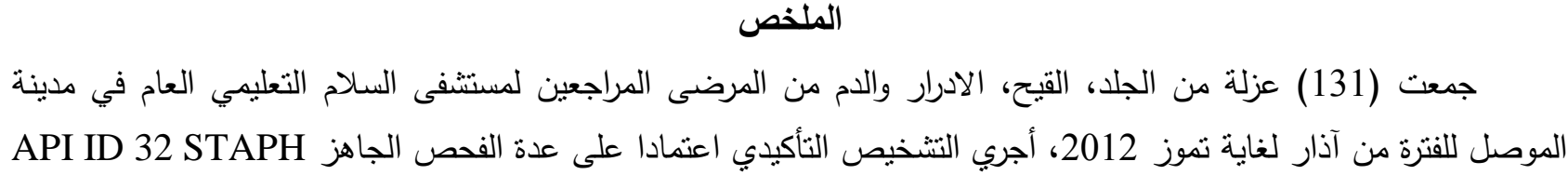

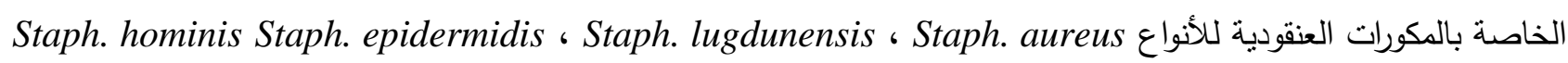
.Staph. haemolyticus و Staph. auricularis ،

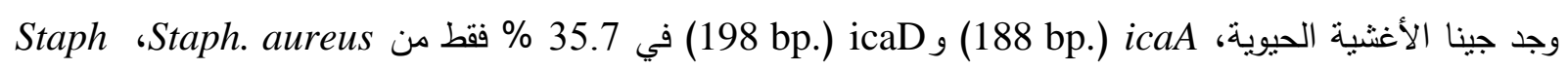

و Staph. hominis ،Staph. epidermidis ،Staph. aureus بينما Staph. xylosus و 42.8 و hنminis

Staph. xylosus

الكلمات الدالة: : Staphylococcus, icaA, icaD.

\section{INTRODUCTION}

Members of the genus Staphylococcus are gram positive cocci that occur singly, in pairs, tetrads, short chains (three or four cells), and irregular grape-like clusters. They are non-motile, non-spore-forming, and usually un-encapsulated or have limited capsule formation. Most species are facultative anaerobes and positive to catalase test (Dworkin et al., 2006).

Staphlyococcus spp. can form a biofilm on nearly any synthetic polymers used as prosthetic devices. In addition, they can bind to blood, matrix proteins, and human cell receptors. Staph. epidermidis is regarded as a leading species in causing chronic polymer-associated clinical infection (Mack et al., 2013).

Colonization of tissues or implants is frequently a first step in infection; and biofilm formation plays a crucial role. One can imagine that the observed genetic variability in biofilm formation, which ranges from super to non-biofilm formers, underlies a well-directed survival and 
spreading program that we are only gradually learning to understand. Once a Staphylococcal biofilm is formed, the cells are nearly invulnerable. They are then shielded from the immune system and resist antibiotic treatment. Therefore, it is very important to understand the various aspects of biofilm formation, it is suggested that to develop more specific ways of overcoming Staphylococcal resistance in chronic infections (Pitts et al., 2003 and Romeo, 2008).

\section{Sample Collection:}

\section{MATERIALS AND METHODS}

One hundred thirty one samples were collected clinically from patients (skin, pus, urine and blood) of both sexes sufferings from bacterial resistant to most antibiotics at Al-Salam General Teaching Hospital, in Mosul city from March to July, 2012. Samples were collected by transport media and sterile swabs damped in normal saline. Isolation and identification were carried out using standard microbiological methods all isolates were identified by API ID 32 STAPH system (Bio Merieux).

\section{Genes detection:}

Ica A gene (188 bp.) was amplified using primers F (5'-ACA CTT GCT GGC GCA GTC AA3'), R (5'-TCT GGA ACC AAC ATC CAA CA-3') and Ica D gene (198 bp.) was amplified using primers F (5'-ATG GTC AAG CCC AGA CAG AG-3'), R (5'-AGT ATT TTC AAT GTT TAA AGC AA-3') (Alpha DNA Company, Montreal, Quebec-CANADA) and the sequences were checked out depending on the Gen Bank Sequence Database (http://www.ncbi.nlm.nih.gov/). The PCR mixtures (12.5 $\mu$ l GoTaq Green Master Mix, $5.5 \mu$ l Nuclease Free Water, $1 \mu$ l Forward Primer, $1 \mu 1$ Reverse Primer and $5 \mu 1$ Extracted DNA, Promega Corporation-USA).

The program is first $2 \mathrm{~min}$ at $94^{\circ} \mathrm{C}$, followed by twenty five cycles at $94^{\circ} \mathrm{C}$ for $1 \mathrm{~min}, 52^{\circ} \mathrm{C}$ for $1 \mathrm{~min}$, and $72^{\circ} \mathrm{C}$ for $2 \mathrm{~min}$ and followed with final extension at $94^{\circ} \mathrm{C}$ for 4 min and cooling $4^{\circ} \mathrm{C}$ for $3 \mathrm{~min}$. The presence of a PCR bands were confirmed by $1 \%(\mathrm{wt} / \mathrm{vol})$ agarose gel electrophoresis and visualization with ethidium bromide (Mariana et al., 2009).

\section{RESULTS AND DISCUSSION}

The results obtained from API test were as follows: four isolates were Staph. aureus; three isolates were Staph. lugdunensis; two isolates were Staph. epidermidis; two isolates were Staph. hominis; one isolate was Staph. auricularis and one isolate was Staph. haemolyticus, the ica locus which is required for the synthesis of the polysaccharide intracellular adhesion (PIA) of Staphylococcus plays a role in cell to cell interactions during biofilm formation and is predominantly present in clinical isolates (Ando et al., 2004).

icaA:

The species Staph. hominis, Staph aureus and Staph xylosus only contain the gene of biofilm which form $35.7 \%$ (icaA 188 bp.). Fig. (1).

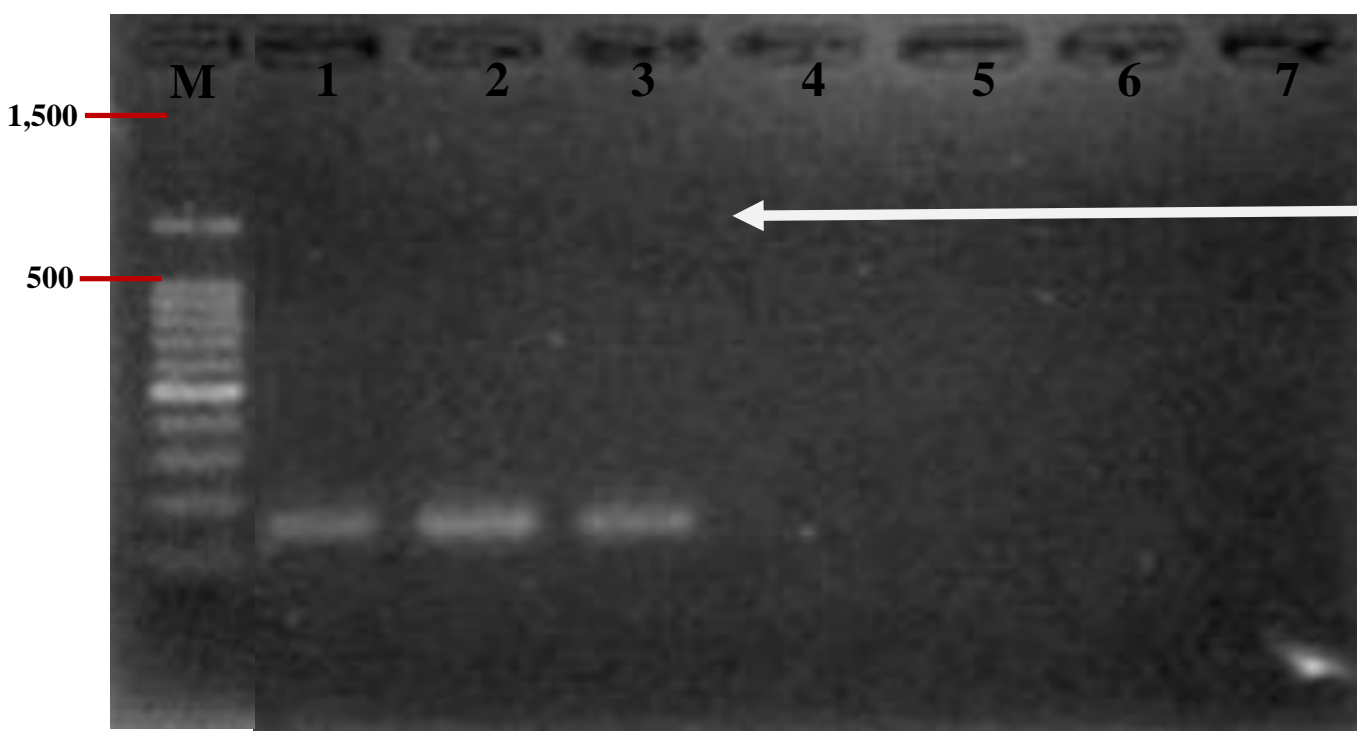

188 bp.

Fig. 1: Staphylococcus spp. icaA gene. 
Five isolates contain icaA gene. Mariana and coworkers, (2009) stated that Staph. aureus and Staph. epidermidis contained this gene, and Nasr and colleagues, (2012) found icaAD genes in (32.0\%) of Staphylococcal isolates, biofilm formation causes catheter associated and nosocomial infections with the presence of icaA and icaD genes (Arciola et al., 2001).

icaD:

The species Staph. hominis, Staph. epidermidis, Staph aureus and Staph xylosus contain the gene of biofilm which form $42.8 \%$ (icaD 198 bp.) Fig. (2).

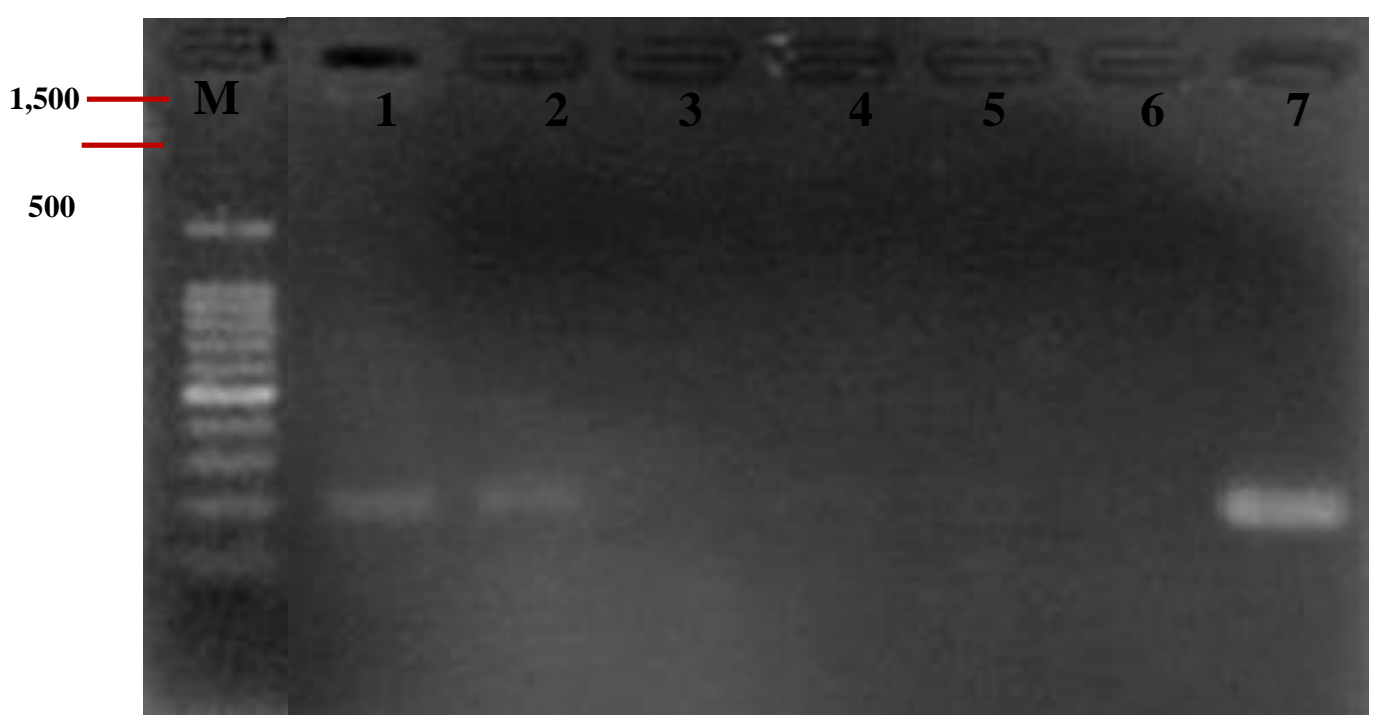

198 bp.

Fig. 2: Staphylococcus spp. icaD gene.

Yazdani and their collaegues (2006) and Nasr and their workers (2012) indicated a high prevalence of the icaAD gene among Staph. aureus isolates and their presence is not always associated with in vitro formation of slime or biofilm, Cafiso and coworkers, (2004) recorded that (35\%) of Staphylococcus spp. contained icaA and icaD genes and some of them carried icaD gene only, Satorres and Alcaraz, (2007) found that (35.2\%) and (48.4\%) of Staph. aureus and Staph. epidermidis strains contained icaA and icaD genes respectively, Mariana and colleagues, (2009) recorded that all Staphylococcus spp. under test were containing this gene, Mahmoud Gad and coworkers, (2009) stated that both icaA and icaD genes were parts of one operon and so the entire operon was either present in or absent and they found that all Staphylococci isolated from catheter segments showed a higher extent of biofilm production than those isolated from urine samples.

\section{REFERENCES}

Ando, E.; Monden, K.; Mitsuhata, R.; Kariyama, R.; Kumon, H. (2004). Biofilm formation among methicillin-resistant Staphylococcus aureus isolates from patients with urinary tract infection. Acta. Med. Okayama, 58(4), 207-214.

Arciola, C.; Baldassari, L.; Montanaro, L. (2001). Presence of icaA and icaD genes and slime production in a collection of Staphylococcal strains from catheter-associated infections. $J$. Clin. Microbiol., 39(6), 2151-2156.

Cafiso, V.; Bertuccio, T.; Santagati, M.; Campanile, F.; Amicosante, G.; Perilli, M.; Selan, L.; Artini, M.; Nicoletti, G.; Stefani, S. (2004). Presence of the ica operon in clinical isolates of Staphylococcus epidermidis and its role in biofilm production. Clin. Microbiol. Infect., 10(12), 1081-1088. 
Dworkin, M.; Falkow, S.; Rosenberg, E.; Schleifer, K.; Stackebrandt, E. (2006). "The Prokaryotes A Handbook on the Biology of Bacteria". $3^{\text {rd }}$ ed. Vol. 1. Springer Science Business Media, Inc. USA. 5-75p.

Mack, D.; Davies, A.; Harris, L.; Jeeves, R.; Pascoe, B.; Knobloch, J.; Rohde, H.; Wilkinson, T. (2013). "Staphylococcus epidermidis in Biomaterial-Associated Infections. Springer Science Business Media". Inc. USA. pp. 25-56.

Mahmoud Gad, G.; El-Feky, M.; El-Rehewy, M.; Hassan, M.; Abolella, H.; Abd El-Baky, R. (2009). Detection of icaA, icaD genes and biofilm production by Staphylococcus aureus and Staphylococcus epidermidis isolated from urinary tract catheterized patients. J. Infect. Dev. Ctries., 3(5), 342-351.

Mariana, N.; Salman, S.; Neeba, V.; Zamberi, S. (2009). Evaluation of modified congo red agar for detection of biofilm produced by clinical isolates of methicillin resistance Staphylococcus aureus. African J. Microbiol. Rese., 3(6), 330-338.

Nasr, R.; AbuShady, H.; Hussein, H. (2012). Biofilm formation and presence of icaAD gene in clinical isolates of Staphylococci. Egyp. J. Med. Human Gen., 13(3), 269-274.

Pitts, B.; Hamilton, A.; Zelver, N.; Stewart, P. (2003). A microtiter-plate screening method for biofilm disinfection and removal. J. Microbiol. Methods., 54(2), 269-276.

Romeo, T. (2008). "Bacterial Biofilms. Springer-Verlag Berlin Heidelberg". Germany. pp. 207-223.

Satorres, S.; Alcaraz, L. (2007). Prevalence of icaA and icaD genes in Staphylococcus aureus and Staphylococcus epidermidis strains isolated from patients and hospital staff. Cent. Eur. J. Public Health, 15(2), 87-90.

Yazdani, R.; Oshaghi, M.; Havayi, A.; Pishva, E.; Salehi, R.; Sadeghizadeh, M.; Foroohesh, H. (2006). Detection of icaAD gene and biofilm formation in Staphylococcus aureus isolates from wound infections. Iranian J. Publ. Health, 35(2), 25-28. 